\title{
Significance of Personnel Recruitment in Implementation of Computer Aided Design Curriculum of Architecture Schools
}

\author{
Kelechi Ezeji ${ }^{1}$ \\ ${ }^{1}$ Department of Architecture, Chukwuemeka Odumegwu Ojukwu University, Uli Campus, Uli Nigeria
}

\begin{abstract}
The inclusion of relevant content in curricula of architecture schools is vital for attainment of Computer Aided Design (CAD) proficiency by graduates. Implementing this content involves, among other variables, the presence of competent tutors. Consequently, this study sought to investigate the importance of personnel recruitment for inclusion of content vital to the implementation of CAD in the curriculum for architecture education. This was with a view to developing a framework for appropriate implementation of CAD curriculum. It was focused on departments of architecture in universities in south-east Nigeria which have been accredited by National Universities Commission. Survey research design was employed. Data were obtained from sources within the study area using questionnaires, personal interviews, physical observation/ enumeration and examination of institutional documents. A multi-stage stratified random sampling method was adopted. The first stage of stratification involved random sampling by balloting of the departments. The second stage involved obtaining respondents' population from the number of staff and students of sample population. Chi Square analysis tool for nominal variables and Pearson's product moment correlation test for interval variables were used for data analysis. With $\rho<0.5$, the study found significant correlation between the number of CAD literate academic staff and use of CAD in design studio/assignments; that increase in the overall number of teaching staff significantly affected total CAD credit units in the curriculum of the department. The implications of these findings were that for successful implementation leading to attainment of CAD proficiency to occur, CADliteracy should be a factor in the recruitment of staff and a policy of in-house training should be pursued.

Key words: Computer-aided-design, education, personnel, curriculum, proficiency.
\end{abstract}

Keywords: Computer-aided design, Education, Personnel recruitment, Curriculum.

\section{Introduction}

Computer-aided design (CAD) is the use of computer technology for design and design documentation [1]. CAD skills are vital to architectural practice. Literature has documented inclusion of CAD courses into curricula of various universities in Nigeria [2][3]. [4] however, opines that notwithstanding the high demand for CAD literate graduates, Nigerian universities still produced CAD-illiterate graduates. [5] notes that the extent and rate of implementation of CAD instruction through the curriculum are still not agreed, though this is explicitly required by the accrediting body for universities, (National Universities Commission (NUC)) in its documentation. Notwithstanding this requirement by the NUC an examination of course handbooks from different architecture schools showed disparities in content and time allocation to CAD. This suggested the lack of a uniform basis for determining appropriate content to include in the curriculum. A consequence of this is that there is no apparent uniform minimum expected level of skill attainment in this area across institutions, hence a great disparity in results for proficiency tests, i.e. graduates from one institution may acquire needed skills through its curriculum, while others have to acquire these skills outside their official training period.

The objective of the study was to examine the level of staffing available in Architecture Departments in Nigerian Universities and its impact on inclusion of CAD content in curriculum in architecture schools. This was with a view to developing a framework for guiding successful implementation for CAD instruction. The research sought to understand the relationship between availability of personnel and provision of CAD content in 
curriculum in architecture schools. Its focus hypothesis was that there is no significant relationship between number of CAD literate academic staff and the use of CAD in design studio/assignments in architecture schools in south-east Nigeria.

The research is justified because CAD proficiency is a goal in architectural education. This makes it necessary to provide necessary content and relevant factors to ensure achievement within the environment of competition by other knowledge areas in the curriculum. Also, in the context of CAD proficiency expectations, understanding the impact of the personnel factor will influence the introduction of content, adoption of methodologies and provision of tools that will achieve it. It will also facilitate proper training in the area of CAD. The study area was south-east Nigeria, located in West Africa.

\section{Literature Review}

\subsection{Theoretical Framework}

Talcott Parsons' adaptation of Systems Theory to expand the theory of structural functionalism was chosen to undergird the wider research. Here, CAD learning in architectural education is seen as part of the socialisation process and viewed as a system composed of four parts namely: CAD Content in curriculum; CAD Funding available for implementation; CAD Equipment and Infrastructure; CAD Personnel available to teach CAD content. CAD proficiency should be achieved if these four components interact according to prescribed 'norms and values'. The quality of proficiency would be lowered if there is a breakdown in interaction, however. This particular aspect of the study sought to ascertain and establish the relationship between the personnel component and the content component in the system.

\subsection{Review of Empirical Literature}

[6] noted that digital immigrant instructors, because they spoke an outdated language (that of the pre-digital age), were struggling to teach a population that speaks an entirely new language. [7] identified teachers' computer competence as a major predictor of integrating ICT in teaching. It noted that literature suggested that majority of teachers who reported negative or neutral attitude towards the integration of ICT into teaching and learning processes lacked knowledge and skills that would allow them to make "informed decision". It also informed that literature showed evidence that teachers' computer self-efficacy, described as a judgement of their capability to use computers (perception of ease of computer use and realization of given tasks) had a significant relationship with implementation of ICT. [8] posited that low computer literacy level was a critical factor that affected the acceptability of ICT by teachers and students in educational institutions. It also averred that many tertiary institutions in Nigeria lacked sufficient numbers of staff skilled in the use of computers for all aspects of the university work including teaching and learning. Widespread adoption of the technologies was therefore slow.

\section{Research Methodology}

This study was part of a wider research on Implementation of CAD in curriculum of NUC accredited departments of architecture in south-east Nigeria. Survey research design method was employed. Data was obtained from primary sources within the study area using questionnaires. A multi-stage stratified random sampling method was adopted to obtain the study population. The first stage of stratification involved the accredited architecture departments in universities in south-east Nigeria. From a list which included seven universities, stratification was done according to the nature of funding of their institutions, i.e. Federal, State and Private. Two institutions were federal-funded, four state funded and one private-funded. Random sampling by balloting was then carried out to pick representation from each pool for the sample. A second sample was taken from the State-funded pool because of the larger number in the pool. Table 1 shows the listed accredited institutions in their categories. 
TABLE 1: List of NUC Accredited Departments of Architecture in South-East Nigeria Categorized by Funding/Ownership Structure

\begin{tabular}{|c|c|c|c|c|c|c|c|c|c|}
\hline $\begin{array}{l}\mathrm{S} / \\
\mathrm{N}\end{array}$ & Federal & $\begin{array}{l}\text { Staff } \\
\text { No. }\end{array}$ & $\begin{array}{l}\text { Students } \\
\text { No. }\end{array}$ & State & $\begin{array}{l}\text { Staff } \\
\text { No. }\end{array}$ & $\begin{array}{l}\text { Students } \\
\text { No. }\end{array}$ & Private & $\begin{array}{l}\text { Staff } \\
\text { No. }\end{array}$ & $\begin{array}{l}\text { Students } \\
\text { No. }\end{array}$ \\
\hline 1 & $\begin{array}{l}\text { Nnamdi Azikiwe } \\
\text { University }\end{array}$ & & & Abia State University & & & $\begin{array}{c}\text { Caritas } \\
\text { University }\end{array}$ & 11 & 71 \\
\hline 2 & $\begin{array}{l}\text { University of } \\
\text { Nigeria }\end{array}$ & 19 & 307 & $\begin{array}{l}\text { Enugu State University of } \\
\text { Science and Technology }\end{array}$ & & & & & \\
\hline 3 & & & & $\begin{array}{c}\text { Chukwuemeka Odumegwu } \\
\text { Ojukwu University }\end{array}$ & 21 & 164 & & & \\
\hline 4 & & & & Imo State University & 20 & 278 & & & \\
\hline
\end{tabular}

Source: [9]

The following were picked: Federal: - (i.) University of Nigeria (UNN); State: - (i.) Chukwuemeka Odumegwu Ojukwu University (COOU), (ii.) Imo State University (IMSU); Private: - (i.) Caritas University (CARITAS). At the second stage, the numbers of staff and students for each sampled department were obtained and sampling size formulae applied to obtain respondents' number. For data analysis, Chi Square analysis tool for nominal variables and Pearson's product moment correlation analysis tool for interval variables were used.

\section{Presentation of Results}

When CAD literacy of staff was checked, the results showed that at all the institutions, the majority of respondents indicated that they were CAD literate. At COOU, the proportion was $81.3 \%$, at IMSU $100 \%$, at CARITAS, $87.5 \%$ and at UNEC, $92.3 \%$. This is illustrated by Table 2 .

TABLE 2: Area-Wise Data on Number of CAD-Literate Academic Staff

\begin{tabular}{ccccccccc}
\hline Value label & \multicolumn{2}{c}{ COOU } & \multicolumn{2}{c}{ IMSU } & \multicolumn{2}{c}{ CARITAS } & \multicolumn{2}{c}{ UNEC } \\
\cline { 2 - 9 } & $\%$ & Cum $\%$ & $\%$ & Cum $\%$ & $\%$ & Cum $\%$ & $\%$ & Cum \% \\
\hline Yes & 81.3 & 81.3 & 100.0 & 100.0 & 87.5 & 87.7 & 92.3 & 92.3 \\
No & 18.8 & 100.0 & 0.0 & 100.0 & 12.5 & 100.0 & 7.7 & 100.0 \\
Total & 100.0 & & 100.0 & & 100.0 & & 100 & \\
\hline
\end{tabular}

Source: Fieldwork, 2015

With the exception of CARITAS, all the schools were overwhelmingly positive in their indication of use of CAD in design and assignments. At COOU, $83.6 \%$ of respondents indicated 'yes', at IMSU it was $76.8 \%$ and at UNEC, 94.9\%. At CARITAS however, only a third (34.5\%) said 'yes' while two-thirds (65.5\%) said 'no'. This is illustrated in Figure 1.

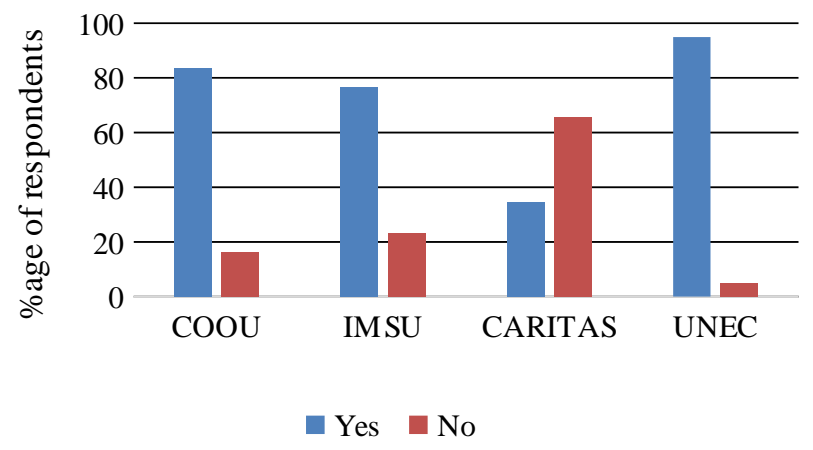

Fig. 1: Appraisal of institutions on use of CAD in design/assignments Source: Fieldwork, 2015

Literacy in the use of CAD software was also asked. The results showed that most (89.6\%) of the respondents indicated they were literate in CAD software. Only a tenth indicated they were not literate in the use any CAD software. This is illustrated by Table 3. 
TABLE 3: Aggregated Data on Number of CAD Literate Academic Staff

\begin{tabular}{ccc}
\hline Value label & $\%$ & Cum \% \\
\hline Yes & 89.6 & 89.6 \\
No & 10.4 & 100 \\
Total & 100.0 & \\
\hline
\end{tabular}

Source: Fieldwork, 2015

The results showed that most of the respondents $(80.3 \%)$ indicated they used CAD in design and other assignments. This indicated very high awareness. This is illustrated by Table 4.

TABLE 4: Aggregated Data on Use of CAD in Design

\begin{tabular}{ccc}
\hline Value label & $\%$ & Cum \% \\
\hline Yes & 80.3 & 80.3 \\
No & 19.7 & 100.0 \\
Total & 100.0 & \\
\hline
\end{tabular}

Source: Fieldwork, 2015

The results showed that only a quarter of staff respondents indicated they were involved in the teaching of CAD courses. The majority were not involved. This is illustrated by Figure 2 .

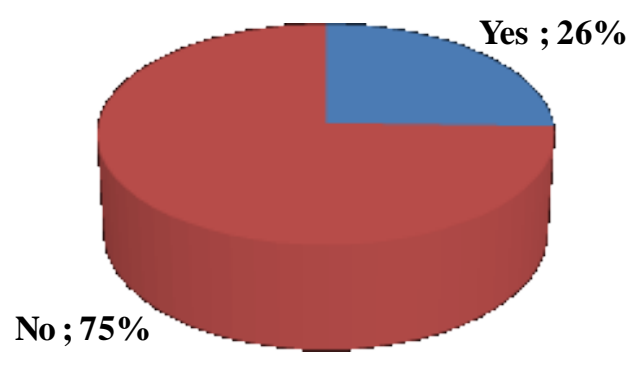

Fig. 2: Analysis of number of academic staff who teach CAD

Source: Fieldwork, 2015

The results showed that most of the respondents were from departments of architecture who had the number of teaching staff within the range of 21-30 staff. This is illustrated by Figure 3.

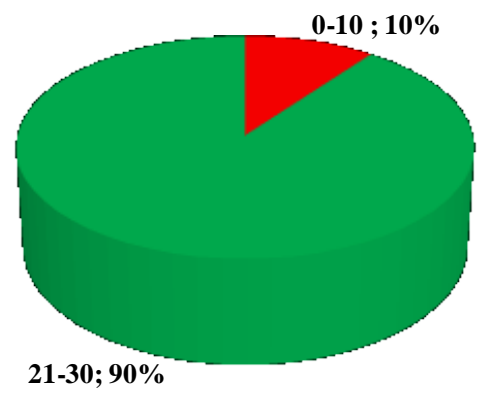

Fig. 3: Analysis of number of teaching staff Source: Fieldwork, 2015

\section{Discussion}

The objective was 'to examine the level of staffing available and its impact on inclusion of CAD content in curriculum in departments of architecture in South-east Nigeria'. Chi-square test of independence analysis tool was used to examine the nature of relationship because the variables were nominal. The result of the analysis showed a p-value of 0.008 . This indicates high significance. It can thus be concluded that there is a highly significant relationship between the two variables. The null hypothesis is therefore rejected and the alternative 
accepted. This alternate hypothesis states that 'There is significant relationship between 'number of CAD literate academic staff' and 'use of CAD in design studio/assignments' in departments of architecture in south-east Nigeria'. The results are shown in Table 5.

TABLE 5: Result of Chi-Square Test of Independence Analysis of Relationship Between CALS and UCD

\begin{tabular}{|c|c|c|}
\hline \multirow[b]{2}{*}{ Number of CAD literate academic staff } & & esign studio/assignments \\
\hline & $\begin{array}{c}\text { Chi-Square } \\
\text { Df } \\
\text { P-Value }\end{array}$ & $\begin{array}{c}6.981 \\
1 \\
.008\end{array}$ \\
\hline
\end{tabular}

Source: Fieldwork, 2015

Also examined was the relationship between 'Number of teaching staff' (NOTS) and 'total CAD credit units in the curriculum' (TCU). The examination of this relationship was also of interest because it directly relates to the objective. Pearson's product moment correlation analysis tool was used to examine the nature of relationship. The result of the analysis showed a Pearson's correlation coefficient value of 1.000 with a significance value point of 0.000 . This is shown in Table 6. It implies a very high, positive relationship exist between the two variables and indicates a perfect correlation. Also, a significance value of 0.000 indicates very high significance. It can thus be concluded that there is a very highly significant, positive relationship between the number of teaching staff and total CAD credit units in the curriculum. An increase in the number of academic staff is likely to lead to an increase in the CAD content included.

TABLE 6: Pearson's Product Moment Correlation Analysis Result of Relationship Between NOTS and TCU

\begin{tabular}{lll}
\hline \multirow{3}{*}{ Number of teaching staff } & & Total CAD credit units in the curriculum \\
\cline { 2 - 3 } & Pearson Correlation & 1.000 \\
& Sig. (2-tailed) & .000 \\
& $\mathrm{~N}$ & 293 \\
\hline
\end{tabular}

Source: Fieldwork, 2015

\section{Recommendation}

While investigating the level of staffing available and its impact on inclusion of CAD content in curriculum in the study area, it was established that:

i. the number of CAD literate academic staff had a significant relationship with the use of CAD in design/assignments

ii. the number of $\mathrm{CAD}$ teachers had no significant relationship with total CAD credit units in the curriculum

iii. the overall number of teaching staff had a significant relationship with the total CAD credit units in the curriculum of the department.

From these, it was deduced that among the variables examined, the most critical personnel variable for positively influencing the inclusion of CAD content and hence its use in the curriculum, was the number of CAD-literate academic staff. It is recommended therefore that

i. Not only should competent staff be recruited, but that CAD-literacy should be a factor in recruitment. This will go a long way in determining extent of inclusion of CAD content as well as acceptance of the department to implement required needs for successful CAD training.

ii. The number of CAD-literate staff be increased through the provision of CAD training opportunities by the institutions. In-house CAD training should be done and funding provided for external CAD-training workshops. The leveraging of CAD training/equipment provision partnerships can also be useful as stated. This should lead to the reduction in fear for the new technologies by the older age groups and acquisition of new perspectives from which to teach in a digital era. 


\section{Conclusion}

Personnel to implement CAD curriculum was a most critical factor. In departments of architecture, personnel act as administrators, curriculum creators as well as implementers. Quantity of personnel though important was less relevant than the CAD literacy of academic staff. Increased CAD literacy amongst staff led to increased inclusion and use of CAD content. This ultimately led to better CAD curriculum implementation. Though the majority of academic staff in the study population were 'digital immigrants' CAD literacy positively affected perception, adoption and use by departments. Provision of CAD training opportunities for staff would positively assist implementation.

\section{References}

[1] "CAD Software", Autodesk.com, 2015. [Online]. Available: http://www.autodesk.com/solutions/cad-software. [Accessed: 21- Jun- 2015]

[2] O. Ogunsote, B. Procnal-Ogunsote and N. Umaru, "Curricular Anatomy of the CAD Proficient Architectural Graduates in Nigeria", $\quad$ sdngnet.com, 2006.2 Available: http://sdngnet.com/Files/Papers/Conference\%20Papers/Curricular\%20Anatomy\%20of\%20the\%20CAD\%20Proficent \%20Architecture\%20Graduate\%20in\%20Nigeria.pdf. [Accessed: 21- Jun- 2015].

[3] O. Olaniyi and F. Olusola, "Computer: A Versatile and Veritable Interactor in Architectural Education in Nigeria", The Nigerian Academic Forum, vol. 21, no. 1, pp. 38-42, 2011.

[4] B. Procnal-Ogunsote and O. Ogunsote, "Developing Workable Standards for Design Studio E-Portfolios in Architectural Education in Nigeria", ARCHES Journal, vol. 8, no. 1, pp. 39-55, 2009

[5] O. Ogunsote, "Three-Dimensional Modelling in AutoCAD 2000: Production of Drawings Using Multiple Layers and Layouts in Paper Space", Journal of the Association of Architectural Educators in Nigeria (AARCHESJ), vol., pp. 8286, 2001.

[6] M. Prensky, "Digital Natives, Digital Immigrants Part 1", On the Horizon, vol. 9, no. 5, pp. 1-6, 2001. https://doi.org/10.1108/10748120110424816

[7] C. Buabeng-Andoh, "Factors influencing teachers' adoption and integration of information and communication technology into teaching: A review of the literature", International Journal of Education and Development using Information and Communication Technology, 8(1),, vol. 8, no. 1, pp. 136-155, 2012.

[8] O. Begho, "i-Connect Project: Mobile solution to support ICT and Education in Nigeria", Futuresoft-ng.com, 2010. [Online]. Available: http://www.futuresoft-ng.com/IT-Talk-Articles/i-connect-project.html. [Accessed: 21- Nov2017].

[9] "Federal Universities | National Universities Commision", Nuc.edu.ng, 2017. [Online]. Available: http://nuc.edu.ng/nigerian-univerisities/federal-univeristies/. [Accessed: 21- Nov- 2017] 